\title{
Prevalence and Predictors of Osteoporosis Among the Chinese Population in Klang Valley, Malaysia
}

\author{
Shaanthana Subramaniam ${ }^{1}$, Chin-Yi Chan ${ }^{1}$, Ima-Nirwana Soelaiman ${ }^{1}$, Norazlina Mohamed ${ }^{1}(\mathbb{D}$, \\ Norliza Muhammad ${ }^{1}$, Fairus Ahmad ${ }^{2}$, Mohd Rizal Abd Manaf ${ }^{3}$, Pei-Yuen Ng ${ }^{4}$, \\ Nor Aini Jamil ${ }^{5}(\mathbb{D}$ and Kok-Yong Chin $1, * \mathbb{B}$ \\ 1 Department of Pharmacology, Faculty of Medicine, Universiti Kebangsaan Malaysia, Cheras, \\ Kuala Lumpur 56000, Malaysia; shaanthana_bks@hotmail.com (S.S.); chanchinyi@gmail.com (C.-Y.C.); \\ imasoel@ppukm.ukm.edu.my (I.-N.S.); azlina@ppukm.ukm.edu.my (N.M.); \\ norliza_ssp@ppukm.ukm.edu.my (N.M.) \\ 2 Department of Anatomy, Faculty of Medicine, Universiti Kebangsaan Malaysia, Cheras, \\ Kuala Lumpur 56000, Malaysia; apai.kie@gmail.com \\ 3 Department of Community Health, Faculty of Medicine, Universiti Kebangsaan Malaysia, Cheras, \\ Kuala Lumpur 56000, Malaysia; mrizal@ppukm.ukm.edu.my \\ 4 Faculty of Pharmacy, Universiti Kebangsaan Malaysia, Kuala Lumpur 50300, Malaysia; pyng@ukm.edu.my \\ 5 School of Healthcare Sciences, Faculty of Health Sciences, Universiti Kebangsaan Malaysia, \\ Kuala Lumpur 50300, Malaysia; ainijamil@ukm.edu.my \\ * Correspondence: chinkokyong@ppukm.ukm.edu.my; Tel.: +603-9145-9573
}

Received: 17 March 2019; Accepted: 28 April 2019; Published: 1 May 2019

check for updates

\begin{abstract}
The prevalence of osteoporosis is forecasted to escalate in Malaysia with an increasing elderly population. This study aimed to analyze the prevalence and the risk factors of osteoporosis among middle-aged and elderly Chinese Malaysians. Three hundred sixty seven Malaysian Chinese aged $\geq 40$ years in Klang Valley, Malaysia, were recruited. All subjects completed a structured questionnaire comprised of demographic details, medical history, diet, and lifestyle practices. Body anthropometry and bone mineral density measurements were also performed. The relationship between bone health status and risk factors was determined using multivariate logistic regression. Fifteen-point-three percent of the overall study population and $32.6 \%$ of those aged $\geq 71$ years had osteoporosis. The prevalence of osteoporosis among women (18.9\%) was higher than men $(11.5 \%)$. The significant predictors of osteoporosis were age, body weight, and low monthly income. Lean mass, low education level, and being underweight predicted osteoporosis in women. Lean mass was the only significant predictor of osteoporosis in men. Overall, 15.3\% of the Malaysian Chinese aged $\geq 40$ years from Klang Valley, Malaysia, had osteoporosis. Osteoporosis was associated positively with increased age and low monthly income and negatively with body weight. Therefore, osteoporosis preventive strategies targeting Chinese elderly from a low socioeconomic background is necessary.
\end{abstract}

Keywords: bone mineral density; calcium; exercise; osteoporosis; osteopenia; sex

\section{Introduction}

Osteoporosis is one of the emerging non-communicable diseases worldwide. The ultimate outcome of osteoporosis is fragility fractures, mainly at the spine, hip, and wrist. The escalating morbidity and mortality due to fragility fractures cause a substantial healthcare burden on individuals, families, and society [1]. Globally, 21 million men and 137 million women had a high probability of osteoporotic fracture in the year 2010, and 55\% of them were from Asia [2]. Half of all hip fractures in the world will occur in Asia by 2050 [3]. The population aged over 50 years in Malaysia is expected to increase from 5.3 million in 2013 to 13.9 million in 2050 [4]. Apart from that, an updated hip fracture 
projection in Asia revealed that Malaysia will experience a 3.55-fold increase in hip fracture incidence by 2050 compared to 2018 [5].

Currently, bone mineral density (BMD) determination using dual-energy $X$-ray absorptiometry (DXA) remains as the gold standard in the diagnosis of osteoporosis [6,7]. According to the World Health Organization, a BMD value $\leq-2.5$ standard deviations (SD) of young adult mean (or a T-score $\leq-2.5$ ) indicates osteoporosis, while a T-score between $\leq-1.0$ and $>-2.5$ indicates osteopenia [6]. The prevalence of osteoporosis is not well documented in Malaysia. A large retrospective study by Lee and Khir (1997) reported that the hip fracture incidence in 1996-1997 among Malaysians aged $\geq 50$ years was 90 per 100,000 individuals per year. In addition, Malaysian Chinese were found to have the highest incidence of hip fractures [8]. Lim et al. reported that the prevalence of osteoporosis among postmenopausal women $(n=514$, mean age: $51.07 \pm 5.28$ years) in central Malaysia was $24.1 \%$ [9]. Several small-scale studies revealed that the prevalence of osteopenia/osteoporosis in Chinese (62\%) was higher compared to other ethnicities [10], and $2.7 \%$ of pre-menopausal Chinese women had osteoporosis [11]. Considering the previous evidence, Chinese are the most vulnerable ethnic group suffering from osteoporosis in Malaysia. Further investigations into the risk factors predisposing Malaysian Chinese to osteoporosis are warranted.

In Malaysia, some studies have reported the risk factors associated with osteoporosis. A local study reported that parity, habitual tea consumption, and body mass index (BMI) were the positive predictors of osteoporosis, while the duration of sleep was a negative predictor of osteoporosis among postmenopausal women aged $\geq 50$ years [10]. Lim et al. (2005) found that increased age and longer years since menopause were positively associated with the occurrence of osteoporosis, while body weight, BMI, and waist and hip circumference were negatively associated with osteoporosis among healthy Malaysian women [9]. Studies involving both sexes are very limited, yet they are important because the risk factors may differ between men and women.

This study aimed to determine the prevalence and predictors associated with osteoporosis among Malaysian Chinese aged $\geq 40$ years. We focused on Malaysian Chinese residing in Klang Valley because it is a densely-populated and highly-urbanized area. This study is novel because both Chinese men and women were recruited, allowing comparison of prevalence and risk factors between sexes to be made. It is among the few studies in Malaysia that uses DXA to determine the bone health of the population. The results obtained from this study would be able to show the prevalence of osteoporosis among Malaysian Chinese and the risk factors involved. The data will be useful in strategizing preventive measures to stop the progression of osteoporosis among high-risk individuals.

\section{Materials and Methods}

This cross-sectional study adopted the quota sampling technique to recruit community-living Malaysian Chinese subjects aged $\geq 40$ years living in Klang Valley, Malaysia. Solicitation of subjects was performed from April-December 2018. Invitations with specific inclusion and exclusion criteria were sent to community centers in Klang Valley and advertised in local newspapers and radio stations. Only subjects fulfilling the inclusion criteria in Table 1 were recruited. The total number of subjects recruited in the study was 408 , of which 51 were excluded from the study due to the following reasons: thiazide diuretics users $(n=15)$, glucocorticoids users $(n=24)$, receiving cancer treatment $(n=2)$, having mobility problems $(n=4)$, and did not complete the study procedures $(n=6)$. Finally, data for 367 subjects were used in the present study. Informed consent was obtained from all the subjects before their enrolment. The study was approved by the Research Ethics Committee of Universiti Kebangsaan Malaysia (approval code: UKM PPI/111/8/JEP-2017-761). 
Table 1. Inclusion and exclusion criteria used for this study.

\begin{tabular}{|c|c|}
\hline Inclusion Criteria & Exclusion Criteria \\
\hline Malaysian aged $\geq 40$ years & $\begin{array}{l}\text { Previously diagnosed with metabolic bone diseases (Paget's disease, } \\
\text { osteogenesis imperfect, osteomalacia, rickets) }\end{array}$ \\
\hline \multirow{4}{*}{ Residing in Klang Valley, Malaysia } & $\begin{array}{l}\text { Diagnosed with conditions that alter bone metabolism } \\
\text { (hypo-/hyper-calcemia, hypo-/hyper-thyroidism, } \\
\text { hypo-/hyper-gonadism) }\end{array}$ \\
\hline & $\begin{array}{l}\text { Receiving therapeutic agents that alter bone metabolism (thiazide } \\
\text { diuretics, glucocorticoids, thyroid supplements, anticonvulsants, } \\
\text { antidepressants, osteoporosis treatment agents, etc.) }\end{array}$ \\
\hline & $\begin{array}{l}\text { Having mobility problems, need a walking aid, fractured six months } \\
\text { prior to the screening date, having metal implants at the calcaneus, hip, } \\
\text { spine, or femoral neck }\end{array}$ \\
\hline & Suffered a low impact fracture after the age of 50 years \\
\hline
\end{tabular}

All subjects completed a questionnaire, which included demographic details (ethnicity, occupation, education level, parity, current menstrual status, age of menarche and menopause), medical history, intake of dairy products (milk, yoghurt, and cheese), coffee, tea, and alcohol, and lifestyle practices (smoking habits and physical activity). The subjects were classified based on household income into the bottom $40 \%$ (B40, with household income $<$ RM 7640 or USD 1868), the middle $40 \%$ (M40, with household income RM 7640-RM 15,159 or USD 1868-USD 3707), and top 20\% (T20, with household income $\geq$ RM 15,160 or USD 3707) groups according to data of the Malaysian census [12]. For the intake of dairy products and beverages, the frequency of consumption was determined. For beverages, an intake of less than one unit per week was defined as non-drinker. One unit of milk was defined as $200 \mathrm{~mL}$, while one unit of coffee/tea was defined as one standard cup [13]. Those who consumed beverages or dairy products $3-4$ days per week were defined as regular drinkers. A unit of alcoholic drink referred to a bottle of beer/cider, a glass of wine, or a portion of spirits/strong alcohol according to the National Health Service, U.K. [14]. Due to the low number of subjects who stopped drinking alcohol, both former drinkers and regular drinkers (3-4 days per week) were grouped as "ever drinker". Meanwhile, those who consumed rarely (one or fewer days per month) or never consumed at all were grouped as "non-drinker". In this study, current smokers and those who abstained from smoking within the past 12 months were grouped as "ever smoker". As for calcium supplementation, subjects who consumed at least one tablet of calcium supplement for 3-4 days per week and took it for more than a month were considered as regular consumers.

Physical activity status of subjects was assessed using the International Physical Activity Questionnaire (IPAQ), which is freely available online [15]. The total energy expenditure was determined by the multiplication of the duration (in minutes) and the frequency (days) of walking by a factor of 3.3, moderate intensity by a factor of 4 , and vigorous intensity by a factor of 8 . These were converted to the metabolic equivalent of task (MET) and summed up. Subjects were categorized into inactive, minimally active, or HEPA (health-enhancing physical activity) active based on total MET score or other additional criteria [11,13].

Subjects' standing height without shoes was measured to the nearest $1 \mathrm{~cm}$ using a stadiometer (SECA, Hamburg, Germany). Body weight of subjects with light clothing, but without shoes was measured to the nearest $0.1 \mathrm{~kg}$ using a weighing scale (TANITA, Tokyo, Japan). Body mass index (BMI: $\mathrm{kg} / \mathrm{m}^{2}$ ) was calculated by dividing body weight $(\mathrm{kg})$ by the square of body height $\left(\mathrm{m}^{2}\right)$. BMI was classified as underweight $\left(<18.5 \mathrm{~kg} / \mathrm{m}^{2}\right)$, normal $\left(18.5-24.9 \mathrm{~kg} / \mathrm{m}^{2}\right)$, and overweight $\left(>24.9 \mathrm{~kg} / \mathrm{m}^{2}\right)$ for those aged $<65$ years [16]. Conversely, for subjects aged $>65$ years, a BMI $<22 \mathrm{~kg} / \mathrm{m}^{2}$ was classified as underweight, $22-27 \mathrm{~kg} / \mathrm{m}^{2}$ as normal, and $>27 \mathrm{~kg} / \mathrm{m}^{2}$ as overweight [17]. Subjects' waist circumference was measured between the lowest rib margin and the iliac crest while they maintained their standing position [18]. 
BMD at the lumbar spine (anteroposterior, L1-L4) and left hip, lean body mass, and fat mass were assessed using total body dual-energy X-ray absorptiometry (DXA) (Hologic Discovery QDR Wi densitometer, Hologic, MA, USA). The BMD values (in $\mathrm{g} / \mathrm{cm}^{2}$ ) were converted to a T-score based on the reference values of the Singaporean Chinese population. Bone health status of the subjects was classified according to the World Health Organization (WHO) criteria into osteoporosis (T-score $\leq-2.5$ ), osteopenia (T-score $\leq-1$ and $>-2.5$ ), and normal (T-score $>-1.0$ ). The DXA measurement was performed by an experienced technologist. Daily calibration was conducted using a phantom. The short-term in vivo coefficient of variation for this device was $1.8 \%$ and $1.2 \%$ for lumbar spine and total hip, respectively.

\section{Statistical Analysis}

All statistical analyses were performed using the Statistical Package for Social Science Version 22.0 (IBM, Armonk, NY, USA). Normality of the data was determined using the Kolmogorov-Smirnov test. The relationship between osteoporosis and predictors of interest was determined using a two-step multivariate logistic regression analysis. All continuous variables were entered into the equation using the stepwise method. All dummy-coded categorical predictors (age groups, education level, physical activity status, parity, and menstrual status) were force-entered in the second step. Subjects who were normal or osteopenic were categorized as " 0 ", while those who were osteoporotic were categorized as " 1 ". The dichotomized bone health status was entered as the dependent variable in the logistic regression. The effect size of each predictor was expressed as odds ratio (OR) and $95 \%$ confidence interval (CI). A $p$-value $<0.05$ was considered to be statistically significant.

\section{Results}

The mean age of the subjects was $59.14 \pm 8.96$ years. Out of 367 subjects, $182(49.6 \%)$ were men, while $185(50.4 \%)$ were women. Ninety four percent of the subjects had sedentary jobs, and $95.6 \%$ had an estimated monthly income <RM 7640 (USD 1868). The majority of the subjects had at least a secondary school education (Table 2).

The prevalence of osteoporosis among the subjects ( $40-87$ years) was $11.5 \%$ for men and $18.9 \%$ for women based on their T-score. Besides that, $45.6 \%$ of men and $53.0 \%$ of women had osteopenia. The prevalence of osteoporosis was higher among older age groups, underweight subjects $\left(<18.5 \mathrm{~kg} / \mathrm{m}^{2}\right)$, and menopausal women. Specifically, $39.6 \%$ of the underweight subjects had osteoporosis compared to $13.8 \%$ of subjects with normal BMI $(p<0.05)$. More menopausal women $(25.8 \%)$ suffered from osteoporosis compared to premenopausal women (4.5\%). The prevalence of osteoporosis was not associated with the subjects' job, monthly income, education level, parity, dairy products intake, coffee/tea intake, and lifestyle practices (Table 3).

Stepwise multivariate logistic regression analysis (Table 4) revealed that increased age and low monthly income positively predicted osteoporosis among the subjects $(p<0.05)$, while body weight negatively predicted osteoporosis among them $(p<0.05)$. Older subjects (OR $=1.110,95 \%$ CI: $1.060-1.162)$ and those with a lower monthly income (OR $=11.292,95 \%$ CI: $2.349-54.282)$ had a greater risk of suffering from osteoporosis. Those with higher body weight (OR $=0.885,95 \% \mathrm{CI}$ : $0.840-0.933)$ were less likely to have osteoporosis. Sub-analysis based on sex showed that lean mass (OR $=0.9997,95 \%$ CI: 0.9995-0.9998) negatively predicted osteoporosis among men and women. In addition, being underweight (OR $=3.543,95 \%$ CI: 1.029-12.198) and calcium supplement intake (OR $=4.163,95 \%$ CI: 1.274-13.606) positively predicted the occurrence of osteoporosis among women. Women with a secondary school (OR $=0.112,95 \%$ CI: $0.021-0.589$ ), certificate or diploma (OR $=0.062$, 95\% CI: 0.009-0.453), and university degree or above (OR $=0.03795 \%$ CI: $0.003-0.437$ ) were less likely to develop osteoporosis compared to those with a primary school education or without any formal education. 
Table 2. General characteristics of the study population. B, bottom; M, middle.

\begin{tabular}{|c|c|c|c|}
\hline Variables & Categories & Mean & Standard Deviation \\
\hline \multicolumn{2}{|c|}{ Age (years) } & 59.14 & 8.96 \\
\hline \multicolumn{2}{|c|}{ Age of menarche (years) } & 13.12 & 1.79 \\
\hline \multicolumn{2}{|c|}{ Age of menopause (years) } & 51.31 & 3.44 \\
\hline \multicolumn{2}{|c|}{ Years since menopause (years) } & 10.17 & 7.22 \\
\hline \multirow{6}{*}{ Body Anthropometry } & Weight (kg) & 61.81 & 10.66 \\
\hline & Height (cm) & 161.58 & 8.23 \\
\hline & $\operatorname{BMI}\left(\mathrm{kg} / \mathrm{m}^{2}\right)$ & 23.59 & 3.25 \\
\hline & Body fat $(\%)$ & 33.03 & 6.53 \\
\hline & Lean body mass (kg) & 39.33 & 8.04 \\
\hline & Waist circumference $(\mathrm{cm})$ & 82.47 & 11.17 \\
\hline & & $\mathrm{N}$ & $\%$ \\
\hline \multirow{4}{*}{ Age Range (years) } & $40-50$ & 71 & 19.3 \\
\hline & $51-60$ & 125 & 34.1 \\
\hline & $61-70$ & 128 & 34.9 \\
\hline & 71 and above & 43 & 11.7 \\
\hline \multirow{2}{*}{ Sex } & Male & 182 & 49.6 \\
\hline & Female & 185 & 50.4 \\
\hline \multirow{2}{*}{ Marital Status } & Single & 33 & 9.0 \\
\hline & Married & 334 & 91.0 \\
\hline \multirow{2}{*}{ Nature of Occupation } & Manual & 22 & 6.0 \\
\hline & Sedentary & 345 & 94.0 \\
\hline \multirow{2}{*}{$\begin{array}{l}\text { Estimated Monthly } \\
\text { Income }\end{array}$} & B40 & 351 & 95.6 \\
\hline & M40 & 16 & 4.4 \\
\hline \multirow{3}{*}{ BMI Classification } & Underweight & 53 & 14.4 \\
\hline & Normal & 210 & 57.2 \\
\hline & Overweight & 104 & 28.3 \\
\hline \multirow{4}{*}{ Highest Education Level } & $\begin{array}{l}\text { No formal education or } \\
\text { Primary school }\end{array}$ & 39 & 10.6 \\
\hline & Secondary school & 179 & 48.8 \\
\hline & Certificate/diploma & 89 & 24.3 \\
\hline & $\begin{array}{l}\text { University degree or } \\
\text { above }\end{array}$ & 60 & 16.3 \\
\hline \multirow{3}{*}{ Parity } & Nulliparous & 34 & 18.4 \\
\hline & 1-3 pregnancies & 99 & 53.5 \\
\hline & More than 3 pregnancies & 52 & 28.1 \\
\hline \multirow{3}{*}{ Current Menstrual Status } & Pre-menopause & 31 & 16.8 \\
\hline & Peri-menopause & 22 & 11.9 \\
\hline & Menopause & 132 & 71.4 \\
\hline \multirow{2}{*}{ Diabetes Mellitus } & Yes & 20 & 5.4 \\
\hline & No & 347 & 94.6 \\
\hline \multirow{2}{*}{ Hypertension } & Yes & 74 & 20.2 \\
\hline & No & 293 & 79.8 \\
\hline \multirow{2}{*}{ Hypercholesterolemia } & Yes & 78 & 21.3 \\
\hline & No & 289 & 78.7 \\
\hline \multirow{2}{*}{ Gout } & Yes & 16 & 4.4 \\
\hline & No & 351 & 95.6 \\
\hline
\end{tabular}


Table 3. Bone health status of the study population. HEPA, health-enhancing physical activity. The bolded p-values are statistically significant.

\begin{tabular}{|c|c|c|c|c|c|c|c|c|c|c|}
\hline \multirow{3}{*}{$\begin{array}{l}\text { Demographic } \\
\text { Details }\end{array}$} & \multirow{3}{*}{ Categories } & \multicolumn{8}{|c|}{ Bone Health Status } & \multirow{3}{*}{$p$-Value } \\
\hline & & \multicolumn{2}{|c|}{ Normal } & \multicolumn{2}{|c|}{ Osteopenia } & \multicolumn{2}{|c|}{ Osteoporosis } & \multicolumn{2}{|c|}{ Total } & \\
\hline & & $\mathbf{n}$ & $\%$ & $\mathbf{n}$ & $\%$ & $\mathrm{n}$ & $\%$ & $\mathrm{n}$ & $\%$ & \\
\hline \multirow{5}{*}{$\begin{array}{c}\text { Age } \\
\text { (years) }\end{array}$} & $40-50$ & 30 & 42.3 & 38 & 53.5 & 3 & 4.2 & 71 & 100 & \multirow{5}{*}{$<0.001$} \\
\hline & $51-60$ & 49 & 39.2 & 65 & 52.0 & 11 & 8.8 & 125 & 100 & \\
\hline & $61-70$ & 38 & 29.7 & 62 & 48.4 & 28 & 21.9 & 128 & 100 & \\
\hline & 71 and above & 13 & 30.2 & 16 & 37.2 & 14 & 32.6 & 43 & 100 & \\
\hline & TOTAL & 130 & 35.4 & 181 & 49.3 & 56 & 15.3 & 367 & 100 & \\
\hline \multirow{3}{*}{ Sex } & Male & 78 & 42.9 & 83 & 45.6 & 21 & 11.5 & 182 & 100 & \multirow{3}{*}{$<0.05$} \\
\hline & Female & 52 & 28.1 & 98 & 53.0 & 35 & 18.9 & 185 & 100 & \\
\hline & TOTAL & 130 & 35.4 & 181 & 49.3 & 56 & 15.3 & 367 & 100 & \\
\hline \multirow{3}{*}{$\begin{array}{l}\text { Nature of } \\
\text { Job }\end{array}$} & Sedentary & 121 & 35.1 & 169 & 49.0 & 55 & 15.9 & 345 & 100 & \multirow{3}{*}{0.352} \\
\hline & Manual & 9 & 40.9 & 12 & 54.5 & 1 & 4.5 & 22 & 100 & \\
\hline & TOTAL & 130 & 35.4 & 181 & 49.3 & 56 & 15.3 & 367 & 100 & \\
\hline \multirow{3}{*}{$\begin{array}{l}\text { Monthly } \\
\text { Income }\end{array}$} & B40 & 121 & 34.5 & 177 & 50.4 & 53 & 15.1 & 351 & 100 & \multirow{3}{*}{0.123} \\
\hline & M40 & 9 & 56.3 & 4 & 25.0 & 3 & 18.8 & 16 & 100 & \\
\hline & TOTAL & 130 & 35.4 & 181 & 49.3 & 56 & 15.3 & 367 & 100 & \\
\hline & No formal education and Primary school & 10 & 25.6 & 17 & 43.6 & 12 & 30.8 & 39 & 100 & \\
\hline & Secondary school & 62 & 34.6 & 89 & 49.7 & 28 & 15.6 & 179 & 100 & \\
\hline Education & Certificate/Diploma & 34 & 38.2 & 45 & 50.6 & 10 & 11.2 & 89 & 100 & 0.119 \\
\hline & University degree and above & 24 & 40.0 & 30 & 50.0 & 6 & 10.0 & 60 & 100 & \\
\hline & TOTAL & 130 & 35.4 & 181 & 49.3 & 56 & 15.3 & 367 & 100 & \\
\hline Body Mass & Underweight & 9 & 17.0 & 23 & 43.4 & 21 & 39.6 & 53 & 100 & \\
\hline $\begin{array}{l}\text { Body Mass } \\
\text { Index }\end{array}$ & Normal & 65 & 31.0 & 116 & 55.2 & 29 & 13.8 & 210 & 100 & \\
\hline $\begin{array}{l}\text { Index } \\
\text { (BMI) }\end{array}$ & Overweight & 56 & 53.8 & 42 & 40.4 & 6 & 5.8 & 104 & 100 & $<0.001$ \\
\hline & TOTAL & 130 & 35.4 & 181 & 49.3 & 56 & 15.3 & 367 & 100 & \\
\hline & Nulliparous & 9 & 26.5 & 22 & 64.7 & 3 & 8.8 & 34 & 100 & \\
\hline Parity & 1-3 pregnancies & 27 & 27.3 & 52 & 52.5 & 20 & 20.2 & 99 & 100 & \\
\hline Parity & More than 3 pregnancies & 16 & 30.8 & 24 & 46.2 & 12 & 23.1 & 52 & 100 & 0.416 \\
\hline & TOTAL & 52 & 28.1 & 98 & 53 & 35 & 18.9 & 185 & 100 & \\
\hline & Pre-menopause & 17 & 54.8 & 14 & 45.2 & 0 & 0 & 31 & 100 & \\
\hline Current & Peri-menopause & 9 & 40.9 & 12 & 54.5 & 1 & 4.5 & 22 & 100 & \\
\hline Menstrual & Menopause & 26 & 19.7 & 72 & 54.5 & 34 & 25.8 & 132 & 100 & $<0.001$ \\
\hline & TOTAL & 52 & 28.1 & 98 & 53 & 35 & 18.9 & 185 & 100 & \\
\hline & Iatrogenic & 1 & 12.5 & 7 & 87.5 & 0 & 0 & 8 & 100 & \\
\hline $\begin{array}{l}\text { Reason of } \\
\text { Menonause }\end{array}$ & Natural & 25 & 20.2 & 65 & 52.4 & 34 & 27.4 & 124 & 100 & 0.128 \\
\hline & TOTAL & 26 & 19.7 & 72 & 54.5 & 34 & 25.8 & 132 & 100 & \\
\hline & Regularly & 42 & 36.8 & 55 & 48.2 & 17 & 14.9 & 114 & 100 & \\
\hline Dairy & Do not drink & 88 & 34.8 & 126 & 49.8 & 39 & 15.4 & 253 & 100 & 0.930 \\
\hline Intake & TOTAL & 130 & 35.4 & 181 & 49.3 & 56 & 15.3 & 367 & 100 & \\
\hline & Regularly & 108 & 36.5 & 146 & 49.3 & 42 & 14.2 & 296 & 100 & \\
\hline Coffee/Tea & Do not drink & 22 & 31 & 35 & 49.3 & 14 & 19.7 & 71 & 100 & 0.441 \\
\hline Intake & TOTAL & 130 & 35.4 & 181 & 49.3 & 56 & 15.3 & 367 & 100 & \\
\hline Calcium & Regularly & 17 & 26.2 & 35 & 53.8 & 13 & 20 & 65 & 100 & \\
\hline Supplement & Never & 113 & 37.4 & 146 & 48.3 & 43 & 14.2 & 302 & 100 & 0.182 \\
\hline Intake & TOTAL & 130 & 35.4 & 181 & 49.3 & 56 & 15.3 & 367 & 100 & \\
\hline & Ever-smoker & 25 & 39.1 & 32 & 50.0 & 7 & 10.9 & 64 & 100 & \\
\hline Smoking & Never & 105 & 34.7 & 149 & 49.2 & 49 & 16.2 & 303 & 100 & 0.536 \\
\hline Status & TOTAL & 130 & 35.4 & 181 & 49.3 & 56 & 15.3 & 367 & 100 & \\
\hline & Ever-drinker & 58 & 40.8 & 62 & 43.7 & 22 & 15.5 & 142 & 100 & \\
\hline Alcohol & Never & 72 & 32 & 119 & 52.9 & 34 & 15.1 & 225 & 100 & 0.180 \\
\hline Intake & TOTAL & 130 & 35.4 & 181 & 49.3 & 56 & 15.3 & 367 & 100 & \\
\hline & Inactive & 47 & 35.9 & 62 & 47.3 & 22 & 16.8 & 131 & 100 & \\
\hline Physical & Moderately-active & 56 & 35.2 & 85 & 53.5 & 18 & 11.3 & 159 & 100 & \\
\hline Activity & HEPA-active & 27 & 35.1 & 34 & 44.2 & 16 & 20.8 & 77 & 100 & 0.349 \\
\hline & TOTAL & 130 & 35.4 & 181 & 49.3 & 56 & 15.3 & 367 & 100 & \\
\hline
\end{tabular}


Table 4. Predictors of bone health status of the study population. The bolded p-values are statistically significant.

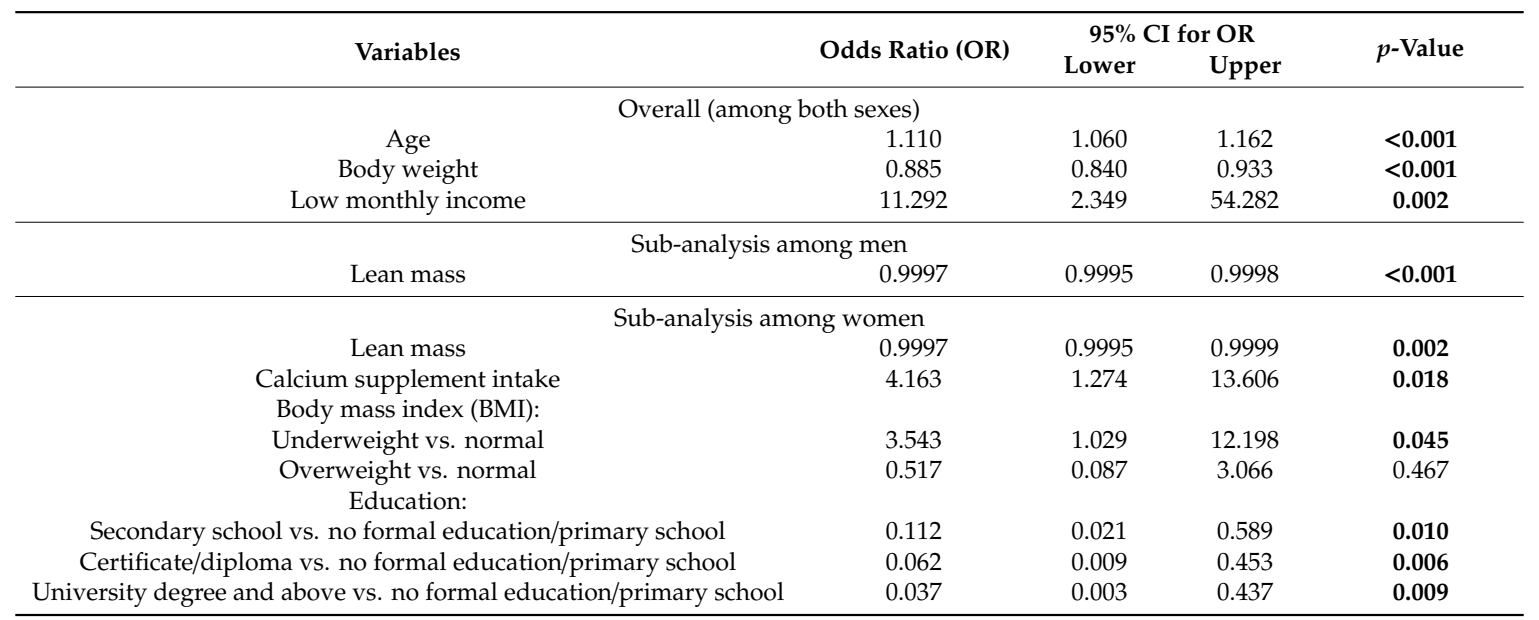

The odds ratio was obtained through a multivariate logistic regression model. The predictors are adjusted to each other.

\section{Discussion}

Osteoporosis is a skeletal metabolic disease with increasing prevalence among the ageing population. In the current study, the prevalence of osteoporosis was higher among older subjects. The prevalence of osteoporosis was $32.6 \%$ in subjects aged $\geq 71$ years compared to subjects in younger age groups ( $4.2 \%, 8.8 \%$, and $21.9 \%$ in age groups $40-50$ years, $51-60$ years, and $61-70$ years, respectively). This was a common finding in many human epidemiological studies. A study conducted in 7163 Koreans aged above 50 years showed that $4.0 \%$ of men in their 50 s were osteoporotic. The prevalence increased to $7.2 \%$ for those in their $60 \mathrm{~s}, 15.1 \%$ in their $70 \mathrm{~s}$, and $26.7 \%$ in their $80 \mathrm{~s}$. The prevalence in women was $15.2 \%, 36.5 \%, 62.7 \%$, and $85.8 \%$, respectively [19]. A similar trend was found in 7042 Han Chinese adults (age range: $20-85$ years), whereby men (21.7\%) and women (59.3\%) in the age group 75-79 years were reported to have the highest prevalence of osteoporosis as compared to other age groups [20]. The pooled prevalence of osteoporosis in 2016 (34.65\%) in China was reported to be twice the pooled prevalence in the year $2006(15.7 \%)$, and the study also observed that osteoporosis increased with age [21]. It was evident that age is one of the most important determinants of osteoporosis.

Women are known to be more susceptible to osteoporosis compared to men. This is due to a phase of accelerated bone loss after menopause [22,23] and a lower peak bone mass in women [24]. In this study, the prevalence of osteoporosis was $18.9 \%$ among women compared to $11.5 \%$ in men. This was in agreement with the study by Lim et al. (2005), which reported that the prevalence of spine and hip osteoporosis among 514 women (mean age: $51.07 \pm 5.28$ years) was $8.6 \%$ and $21.4 \%$, respectively [ 9 ]. In the Korean population ( $n=126,269$; age range: 50-64 years), a 10-fold difference in the prevalence of osteoporosis between women (25.2\%) and men (2.3\%) was observed [25]. Menopausal women in our study had the highest prevalence of osteoporosis compared with premenopausal or perimenopausal women, and this was analogous to previous studies [26,27]. Lim et al. showed that the prevalence of osteoporosis in postmenopausal women $(42.1 \%)$ was four-fold higher than that of premenopausal women (11.1\%) [26]. Another Korean study (1547 men and 1991 women; age range 40-79 years) also found that postmenopausal women were at greater risk for osteoporosis at lumbar spine compared to premenopausal women [27]. After menopause, deprivation of estrogen will alter the composition of the mineral and organic matrix of bone tissue [28,29]. The progressive increase in bone resorption and the decrease in bone formation due to estrogen deficiency will deteriorate the microarchitecture and strength of bones [29].

This study also showed that the prevalence of osteoporosis was higher among underweight subjects compared to those with normal BMI or who were overweight. This was in line with a 
number of previous studies [30-32]. Underweight subjects were shown to have a higher incidence of osteoporosis than those with a BMI $\geq 18.5 \mathrm{~kg} / \mathrm{m}^{2}$ among Mainland Chinese $(\mathrm{n}=4988$, aged 41-95 years). Lower BMI was found to be positively correlated with osteoporosis [30]. A cross-sectional study in Thailand ( $n=4528$, age $\geq 40$ years) also reported that osteoporosis was most commonly found in underweight women $(52.1 \%)$, followed by those with normal weight $(20.3 \%)$, those overweight $(15.7 \%)$, and those obese (9.4\%) [31]. Greater BMI or body weight is positively associated with BMD as it imposes mechanical stress on bone, and in response, the bone mass increases to accommodate the load $[33,34]$. Adipose tissue also possesses aromatase enzyme, which converts androgen to estrogen, which is protective of bone $[35,36]$. BMI may also reflect the nutritional status of the subjects, whereby underweight subjects may be deficient in the vital nutrients to maintain bone health. The positive association between BMI and bone health has been discussed in various geographical regions and populations [37-40]. However, BMI is a poor determinant of obesity, because it is the excess fat mass that actually defines obesity rather than total body weight (or BMI) [33]. Lean mass, which is a component contributing to body weight aside from fat mass, was observed to predict negatively osteoporosis among the subjects of this study. The muscle can also exert mechanical forces on the bone and maintain its mass. It may also reflect the weight-bearing activity of the subjects, in which muscle mass and bone health are higher in those who are more active.

Intake of calcium supplement was a positive predictor of osteoporosis among women in this study. We hypothesized that this observation was caused by the fact that women susceptible to osteoporosis had initiated calcium supplementation prior to joining the study. Calcium supplements have been widely used as a pharmacological agent to prevent bone loss [41-43]. However, the calcium supplementation might not be persistent or sufficient among women in this study to produce an effect on their bone health. Thus, the relationship was not causal.

The majority of the subjects in the present study belonged to the low socio-economic group (95.6\%). A lower monthly household income was found to predict osteoporosis among the subjects, especially women, in this study. This was in accordance with a previous study that reported a significant association between household income and bone health in elderly women [44]. A lower household income may imply limited access to healthcare $[25,45]$. Subjects with a lower income might not have the opportunities to engage with medical professionals to ensure their well-being. Besides, they might not have access to healthy food and supplements. Thus, previous studies have indicated that individuals with a lower income also had a greater risk of hip fracture [46].

Lower education level was one of the determinants of osteoporosis among women. Similar findings were reported by Alalli et al. (2010), whereby a lower education level was associated with a lower BMD and a higher prevalence of osteoporosis in Moroccan women $(n=356$, mean age: $58.9 \pm 7.7$ years) [47]. It is postulated that subjects with lower educational background might have lower knowledge and awareness regarding osteoporosis. Hence, they are less likely to engage in osteoprotective practices. This was confirmed by another study among postmenopausal women ( $\mathrm{n}=$ 560; mean age: $60.43 \pm 7.19$ years), which demonstrated that subjects with a higher education level had a better bone health status and positive practices towards bone health [48].

There are several limitations that should be considered when interpreting the data of this study. The present study was limited by its cross-sectional design. A prospective study would provide stronger evidence of causality between osteoporosis and its associated risk factors. We also did not determine the dietary and supplementation pattern of the subjects in detail; hence, the relationship between macro- and micro-nutrients and bone health was not investigated. An additional limitation includes the relatively smaller sample size involved in the study. However, to the best of our knowledge, this is the first study to report on the prevalence and predictors of osteoporosis defined by DXA among middle-aged and elderly Malaysian Chinese in Klang Valley. Other similar studies have been conducted in Malaysia, but they used quantitative ultrasonometry to determine bone health of the subjects $[13,49,50]$. 


\section{Conclusions}

In conclusion, the crude prevalence of osteoporosis among Malaysian Chinese aged 40 years was $15.3 \%$, while sex-specific prevalence was $11.5 \%$ in men and $18.9 \%$ in women. The positive predictors of osteoporosis among Malaysian Chinese were age and low monthly income, while body weight was found to be a negative predictor. The identification of these risk factors has major implications for the design of early preventive programs against osteoporosis among middle-aged or elderly Chinese population in Malaysia. A special focus should be given to those with low socioeconomic status because they may not have easy access to healthcare facilities that cater to their bone health. Proper health education towards a healthy lifestyle also must be considered since it is a proactive measure to prevent osteoporosis.

Author Contributions: Conceptualization, K.-Y.C., N.M. (Norazlina Mohamed), N.M. (Norliza Muhammad), F.A., M.R.A.M., P.-Y.N., N.A.J. and I.-N.S.; funding acquisition, N.M. (Norazlina Mohamed) and K.-Y.C.; investigation, S.S. and C.Y.C.; methodology, K.-Y.C.; project administration, I.-N.S. and K.-Y.C.; supervision, N.M. (Norazlina Mohamed), N.M. (Norliza Muhammad), F.A., M.R.A.M., P.-Y.N., and N.A.J.; writing, original draft, S.S. and C.Y.C.; writing, review and editing, I.-N.S. and K.-Y.C.

Funding: This research was funded by the postgraduate research grant GUP-2017-060 and the Arus Perdana Grant (AP-2017-009/1) from Universiti Kebangsaan Malaysia.

Acknowledgments: We would like to extend our gratitude to Azlan Mohd Arslamsyah, Mustazil Mohd Noor, Farhana Mohd Fozi, Sabariah Adnan, and Nurul Hafizah Abas from the Department of Pharmacology for their kind assistance.

Conflicts of Interest: The authors declare no conflict of interest.

\section{References}

1. Zha, X.Y.; Hu, Y.; Pang, X.N.; Chang, G.L.; Li, L. Diagnostic value of osteoporosis self-assessment tool for Asians (OSTA) and quantitative bone ultrasound (QUS) in detecting high-risk populations for osteoporosis among elderly Chinese men. J. Bone Miner. Metab. 2015, 33, 230-238. [CrossRef] [PubMed]

2. Odén, A.; McCloskey, E.V.; Kanis, J.A.; Harvey, N.C.; Johansson, H. Burden of high fracture probability worldwide: Secular increases 2010-2040. Osteoporos. Int. 2015, 26, 2243-2248. [CrossRef]

3. Lau, E.M. The epidemiology of osteoporosis in Asia. IBMS BoneKEy 2009, 6, 190-193. [CrossRef]

4. Mithal, A.; Ebeling, P.; Kyer, C.S.; Bansal, B. The Asia-Pacific Regional Audit: Epidemiology, Costs E Burden of Osteoporosis in 2013; International osteoporosis foundation: Nyon, Switzerland, 2013. [CrossRef]

5. Cheung, C.-L.; Ang, S.B.; Chadha, M.; Chow, E.S.-L.; Chung, Y.-S.; Hew, F.L.; Jaisamrarn, U.; Ng, H.; Takeuchi, Y.; Wu, C.-H.; et al. An updated hip fracture projection in Asia: The Asian Federation of Osteoporosis Societies study. Osteoporos. Sarcopenia 2018. [CrossRef]

6. WHO Study Group. Assessment of fracture risk and its application to screening for postmenopausal osteoporosis: Report of a WHO study group [meeting held in Rome from 22 to 25 June 1992]. Osteoporos. Int. 1994, 843, 1-129.

7. Blake, G.M.; Fogelman, I. Role of dual-energy X-ray absorptiometry in the diagnosis and treatment of osteoporosis. J. Clin. Densitom. 2007, 10, 102-110. [CrossRef]

8. Lee, J.K.; Khir, A.S.M. The incidence of hip fracture in Malaysians above 50 years of age: Variation in different ethnic groups. APLAR J. Rheumatol. 2007, 10, 300-305. [CrossRef]

9. Lim, P.S.; Ong, F.B.; Adeeb, N.; Seri, S.S.; Noor-Aini, M.Y.; Shamsuddin, K.; Hapizah, N.; Mohamed, A.L.; Mokhtar, A.; Wan, H.W. Bone health in urban midlife Malaysian women: Risk factors and prevention. Osteoporos. Int. 2005, 16, 2069-2079. [CrossRef] [PubMed]

10. Chan, P.J.; Nurul, Z.Z.; Chuah, J.S.; Nabil, M.M.A.; Isa, N.M.; Sabarul, A.M.; Nazrun, A.S. Association between risk factors of osteoporosis and bone mineral density in women of different ethnic groups in a Malaysian hospital. Int. J. Osteoporos. Metab. Disord. 2014, 7, 1-11.

11. Yee, Y.; Zaitun, Y.; Chan, Y.; Norhaizan, M. Association between anthropometric status, dietary intake and physical activity with bone health status among premenopausal chinese women in the Klang Valley, Malaysia. Malays. J. Nutr. 2013, 19, 293-302. 
12. Department of Statistics. Household Income and Basic Amenities Survey Report 2016; Department of Statistics, Malaysia: Putrajaya, Malaysia, 2016.

13. Chin, K.Y.; Low, N.Y.; Dewiputri, W.I.; Ima-Nirwanaa, S. Factors associated with bone health in Malaysian middle-aged and elderly women assessed via quantitative ultrasound. Int. J. Environ. Res. Public Health 2017, 14, 736. [CrossRef]

14. Sommer, I.; Erkkilä, A.T.; Järvinen, R.; Mursu, J.; Sirola, J.; Jurvelin, J.S.; Kröger, H.; Tuppurainen, M. Alcohol consumption and bone mineral density in elderly women. Public Health Nutr. 2013, 16, 704-712. [CrossRef] [PubMed]

15. Craig, C.L.; Marshall, A.L.; Sjorstrom, M.; Bauman, A.E.; Booth, M.L.; Ainsworth, B.E.; Pratt, M.; Ekelund, U.; Yngve, A.; Sallis, J.F.; et al. International physical activity questionnaire: 12-country reliability and validity. Med. Sci. Sports Exerc. 2003, 35, 1381-1395. [CrossRef] [PubMed]

16. World Health Organization. Obesity: Preventing And Managing The Global Epidemic; World Health Organization: Geneva, Switzerland, 1999.

17. Winter, J.E.; MacInnis, R.J.; Wattanapenpaiboon, N.; Nowson, C.A. BMI and all-cause mortality in older adults: A meta-analysis. Am. J. Clin. Nutr. 2014, 99, 875-890. [CrossRef]

18. Chin, K.-Y.; Soelaiman, I.-N.; Mohamed, I.N.; Ibrahim, S.; Ngah, W.Z.W. The effects of age, physical activity level, and body anthropometry on calcaneal speed of sound value in men. Arch. Osteoporos. 2012, 7, 135-145. [CrossRef]

19. Lee, J.; Lee, S.; Jang, S.; Ryu, O.H. Age-related changes in the prevalence of osteoporosis according to gender and skeletal site: The Korea National Health and Nutrition Examination Survey 2008-2010. Endocrinol. Metab. 2013, 28, 180-191. [CrossRef]

20. Zhu, H.; Fang, J.; Luo, X.; Yu, W.; Zhao, Y.; Li, X.; Du, J.; Lu, Y. A survey of bone mineral density of healthy Han adults in China. Osteoporos. Int. 2010, 21, 765-772. [CrossRef] [PubMed]

21. Chen, P.; Li, Z.; Hu, Y. Prevalence of osteoporosis in China: A meta-analysis and systematic review. BMC Public Health 2016, 16, 1039. [CrossRef]

22. Alswat, K.A. Gender disparities in osteoporosis. J. Clin. Med. Res. 2017, 9, 382. [CrossRef] [PubMed]

23. Yuen, K.W.; Kwok, T.C.; Qin, L.; Leung, J.C.; Chan, D.C.; Kwok, A.W.; Woo, J.; Leung, P. Characteristics of age-related changes in bone compared between male and female reference Chinese populations in Hong Kong: A pQCT study. J. Bone Miner. Metab. 2010, 28, 672-681. [CrossRef] [PubMed]

24. Riggs, B.L.; Khosla, S.; Melton, L.J., III. Sex steroids and the construction and conservation of the adult skeleton. Endocr. Rev. 2002, 23, 279-302. [CrossRef]

25. Noh, J.W.; Park, H.; Kim, M.; Kwon, Y.D. Gender Differences and Socioeconomic Factors Related to Osteoporosis: A Cross-Sectional Analysis of Nationally Representative Data. J. Womens Health (Larchmt.) 2018, 27, 196-202. [CrossRef]

26. Pei Shan, L.; Fee Bee, O.; Seri Suniza, S.; Adeeb, N. Developing a Malaysian Osteoporosis Screening Tool (MOST) for early osteoporosis detection in Malaysian women. Sex. Reprod. Healthc. 2011, 2, 77-82. [CrossRef]

27. Shin, C.S.; Choi, H.J.; Kim, M.J.; Kim, J.T.; Yu, S.H.; Koo, B.K.; Cho, H.Y.; Cho, S.W.; Kim, S.W.; Park, Y.J.; et al. Prevalence and risk factors of osteoporosis in Korea: A community-based cohort study with lumbar spine and hip bone mineral density. Bone 2010, 47, 378-387. [CrossRef]

28. Brennan, M.; Gleeson, J.; Browne, M.; O’Brien, F.; Thurner, P.; McNamara, L. Site specific increase in heterogeneity of trabecular bone tissue mineral during oestrogen deficiency. Eur. Cells Mater. 2011, 21, 396-406. [CrossRef]

29. Brennan, O.; Kuliwaba, J.S.; Lee, T.C.; Parkinson, I.H.; Fazzalari, N.L.; McNamara, L.M.; O’Brien, F.J. Temporal changes in bone composition, architecture, and strength following estrogen deficiency in osteoporosis. Calcifi. Tissue Int. 2012, 91, 440-449. [CrossRef]

30. Cui, R.; Zhou, L.; Li, Z.; Li, Q.; Qi, Z.; Zhang, J. Assessment risk of osteoporosis in Chinese people: Relationship among body mass index, serum lipid profiles, blood glucose, and bone mineral density. Clin. Int. Aging 2016, 11, 887.

31. Rithirangsriroj, K.; Panyakhamlerd, K.; Chaikittisilpa, S.; Chaiwatanarat, T.; Taechakraichana, N. Osteoporosis in different age-groups and various body mass index (BMI) ranges in women undergoing bone mass measurement at King Chulalongkorn Memorial Hospital. J. Med. Assoc. Thail. 2012, 95, 644. 
32. Fawzy, T.; Muttappallymyalil, J.; Sreedharan, J.; Ahmed, A.; Alshamsi, S.O.; Al Ali, M.S.; Al Balsooshi, K.A. Association between body mass index and bone mineral density in patients referred for dual-energy $\mathrm{X}$-ray absorptiometry scan in Ajman, UAE. J. Osteoporos. 2011. [CrossRef]

33. Zhao, L.-J.; Liu, Y.-J.; Liu, P.-Y.; Hamilton, J.; Recker, R.R.; Deng, H.-W. Relationship of obesity with osteoporosis. J. Clin. Endocrinol. Metab. 2007, 92, 1640-1646. [CrossRef]

34. Iwaniec, U.T.; Turner, R.T. Influence of body weight on bone mass, architecture, and turnover. J. Endocrinol. 2016, 230, R115-R130. [CrossRef]

35. Rosen, C.J.; Bouxsein, M.L. Mechanisms of disease: Is osteoporosis the obesity of bone. Nat. Rev. Rheumatol. 2006, 2, 35. [CrossRef]

36. Sasano, H.; Uzuki, M.; Sawai, T.; Nagura, H.; Matsunaga, G.; Kashimoto, O.; Harada, N. Aromatase in human bone tissue. J. Bone Miner. Res. 1997, 12, 1416-1423. [CrossRef] [PubMed]

37. Lloyd, J.T.; Alley, D.E.; Hawkes, W.G.; Hochberg, M.C.; Waldstein, S.R.; Orwig, D.L. Body mass index is positively associated with bone mineral density in US older adults. Arch. Osteoporos. 2014, 9, 175. [CrossRef] [PubMed]

38. Ong, T.; Sahota, O.; Tan, W.; Marshall, L. A United Kingdom perspective on the relationship between body mass index (BMI) and bone health: A cross sectional analysis of data from the Nottingham Fracture Liaison Service. Bone 2014, 59, 207-210. [CrossRef] [PubMed]

39. Marwaha, R.K.; Tandon, N.; Garg, M.K.; Kanwar, R.; Narang, A.; Sastry, A.; Saberwal, A.; Bhadra, K.; Mithal, A. Bone health in healthy Indian population aged 50 years and above. Osteoporos. Int. 2011, 22, 2829-2836. [CrossRef] [PubMed]

40. Barrera, G.; Bunout, D.; Gattas, V.; de la Maza, M.P.; Leiva, L.; Hirsch, S. A high body mass index protects against femoral neck osteoporosis in healthy elderly subjects. Nutrition 2004, 20, 769-771. [CrossRef]

41. Tai, V.; Leung, W.; Grey, A.; Reid, I.R.; Bolland, M.J. Calcium intake and bone mineral density: Systematic review and meta-analysis. BMJ 2015, 351, h4183. [CrossRef]

42. Bauer, D.C. Calcium supplements and fracture prevention. N. Engl. J. Med. 2013, 369, 1537-1543. [CrossRef]

43. Reid, I.R.; Ames, R.W.; Evans, M.C.; Gamble, G.D.; Sharpe, S.J. Effect of calcium supplementation on bone loss in postmenopausal women. N. Engl. J. Med. 1993, 328, 460-464. [CrossRef]

44. Prus, S.G.; Gee, E. Gender differences in the influence of economic, lifestyle, and psychosocial factors on later-life health. Can. J. Public Health/Revue Canadienne de Sante'e Publique 2003, 94, 306-309.

45. Myong, J.-P.; Kim, H.-R.; Choi, S.E.; Koo, J.-W. The effect of socioeconomic position on bone health among Koreans by gender and menopausal status. Calcif. Tissue Int. 2012, 90, 488-495. [CrossRef] [PubMed]

46. Guilley, E.; Herrmann, F.; Rapin, C.-H.; Hoffmeyer, P.; Rizzoli, R.; Chevalley, T. Socioeconomic and living conditions are determinants of hip fracture incidence and age occurrence among community-dwelling elderly. Osteoporos. Int. 2011, 22, 647-653. [CrossRef] [PubMed]

47. Allali, F.; Rostom, S.; Bennani, L.; Abouqal, R.; Hajjaj-Hassouni, N. Educational level and osteoporosis risk in postmenopausal Moroccan women: A classification tree analysis. Clin. Rheumatol. 2010, 29, 1269-1275. [CrossRef] [PubMed]

48. Gur, A.; Sarac, A.J.; Nas, K.; Cevik, R. The relationship between educational level and bone mineral density in postmenopausal women. BMC Fam. Pract. 2004, 5, 18. [CrossRef] [PubMed]

49. Chin, K.-Y.; Soelaiman, I.-N.; Mohamed, I.N.; Mohamed, N.; Shuid, A.N.; Muhammad, N.; Wan Ngah, W.Z. Discrepancy between the quantitative ultrasound value of malaysian men and the manufacturer's reference and the impact on classification of bone health status. J. Clin. Densitom. 2013, 16, 189-195. [CrossRef]

50. Chin, K.Y.; Kamaruddin, A.A.; Low, N.Y.; Ima-Nirwana, S. Effects of age, sex, and ethnicity on bone health status of the elderly in Kuala Lumpur, Malaysia. Clin. Int. Aging 2016, 11, 767-773. [CrossRef]

(C) 2019 by the authors. Licensee MDPI, Basel, Switzerland. This article is an open access article distributed under the terms and conditions of the Creative Commons Attribution (CC BY) license (http://creativecommons.org/licenses/by/4.0/). 